\title{
O Problema da Chefia no Serviço Público
}

$U$

$m$ dos aspectos da administração de pessoal que até hoje têm desafiado a argúcia dos que se dedicam a êsse setor importante do serviço público tem sido o do critério da escolha de chefes.

Com a Lei n. 284, de 1936 - a chamada Lei do Reajus. tamento - introduziu-se uma das reformas mais radicais por que já passou o nosso sistema de pessoal. Um dos pontos mais importantes dessa reforma foi, sem dúvida alguma, o que modificou por completo o critério da escolha de chefes. Passava-se do sistema rígido da chefia permanente -como fim de carreira, até o nível de Diretor ou até mesmo de Diretor-Geral - para o sistema da livre escolha, desde o nível inicial de chefia - chefe de seção.

É que, como tantas vêzes acontece, no afã de corrigir um êrro, passa-se a um excesso contrário, senão ainda pior, pelo menos tão nocivo como o que se procurava sanar.

Agora, ao cabo de quase dois decênios de vigência da Lei do Reajustamento, reconhecidos os inconvenientes de tamanha latitude para o preenchimento dos cargos e funções de chefia no Serviço Público Federal, eis que a Comissão incumbida do Estudo do Plano de Classificação de Cargos, no projeto de lei que elaborou para acompanhar o mesmo, introduziu nova modalidade que, esperamos, representará verdadeiro progresso em matéria de tanta relevância.

Sem voltar à rigidez antiga dos chefes que se eternizavam nos respectivos postos, o projeto de lei ora em estudo 
no Congresso, introduz no nosso sistema de pessoal inovação das mais alvissareiras. Os postos de chefia passarão a ser exercidos, exclusivamente, por funcionários que tenham atingido o final da respectiva carreira, ficando a Adminis tração com plena liberdade para, entre êles, escolher os chefes nos diferentes niveis.

Com isso muito lucrará a Administração, que ficará assim livre das injunções politicas, tantas vêzes prejudiciais à eficiência do serviço pela imposição de chefes ineptos, como, também, o funcionalismo, que se sentirá satisfeito pela certeza de que terá sido eliminado um dos fatôres de desestímulo - o desacêrto de certas escolhas de chefes, muitas vêzes jovens inexperientes, apenas ingressados no serviço público.

Para a vida de um povo, nada é mais importante que o trabalho de direção. Êste exige, necessàriamente, a predominância das elites, o prestígio do mérito e o domínio das competências. E a razão é fácil de compreender. O trabalho de direção implica certas qualidades como a iniciativa, visão do conjunto, capacidade de administração, decisão e senso da oportunidade, qualidades estas que só as melhores cabeças de um país reunem. E' preciso, pois, aproveitá-las convenientemente em benefício da coletividade.

Prof. Humberto Grande, Administração e Trabalho, "R.S.P.", março de 1955. 